\title{
EFFECT OF FOLIAR APPLICATION OF SELENIUM ON NUTRIENT CONCENTRATION AND YIELD OF COLORED- GRAIN WHEAT IN CHINA
}

\author{
XIA, Q. ${ }^{1}-$ YANG, Z. P. ${ }^{1}-$ XUE, N. W. ${ }^{2}-$ DAI, X. J. ${ }^{1}-$ ZhANG, X. ${ }^{1}-$ GAO, Z. Q. ${ }^{1 *}$ \\ ${ }^{I}$ College of Agriculture, Shanxi Agricultural University, Taigu, China \\ ${ }^{2}$ School of Life Sciences, Datong University, Datong, China \\ *Corresponding author \\ e-mail: gaozhiqiang1964@126.com
}

(Received $8^{\text {th }}$ Nov 2018; accepted $25^{\text {th }}$ Jan 2019)

\begin{abstract}
A field experiment was conducted to evaluate the efficiency of foliar application of different concentrations of Se fertilization $\left(37.50,56.25,75.00,93.75\right.$, and $112.50 \mathrm{~g} \mathrm{ha}^{-1}$ of Se) at the early grain filling stage on nutritional quality of colored-grain wheat. The results showed that Se plays a role in influencing the nutrients concentration of colored-grain wheat. When it was more than $75.00 \mathrm{~g} \mathrm{ha}^{-1}$, the Se concentration in the common wheat was excessive. However, when it was more than $37.50 \mathrm{~g} \mathrm{ha}^{-1}$, the Se concentration in the colored-grain wheat was excessive, indicating that colored-grain wheat was likely to be more sensitive to Se accumulation. Se concentration of colored-grain wheat was significantly increased under the optimal foliar application of Se concentration at $37.5 \mathrm{~g} \mathrm{ha}^{-1}$, decreased starch concentration, without affecting the yield. Particularly, the concentrations of gliadin and glutenin were significantly increased while both albumin and globulin were reduced with the increased $\mathrm{Se}$ concentration. Additionally, our research showed that foliar application Se increased the concentration of iron $(\mathrm{Fe})$, zinc $(\mathrm{Zn})$, but decreased the concentration of copper $(\mathrm{Cu})$ and manganese $(\mathrm{Mn})$. More importantly, the intake of Se promoted the production of amino acids and anthocyanins. This indicates the potential roles Se plays on regulating nutrition value in colored-grain wheat.
\end{abstract}

Keywords: Se-enrich, total protein, minerals, amylase, amylopectin

\section{Introduction}

Hidden hunger or micronutrient deficiency occurs when the food quality does not meet the requirements of essential nutrient need for the growth and development of humans. The main cause of hidden hunger is the deficiency of minerals (for examples, selenium, zinc, iron, and iodine), lack of vitamins in diet, and large consumption of staple food (wheat, rice, and maize) which lack these nutrients (Zhao et al., 2016). Hidden hunger is affecting approximately 2 billion people around the world including 300 million people in China (Toppe and Chomo, 2015; Kennedy et al., 2003; Maberly et al., 1994). Many chronic diseases, including diabetes, cardiovascular disease, cancer, and obesity were linked to the imbalance or deficiency of nutrient intake.

Selenium ( $\mathrm{Se}$ ) is an essential trace element for humans and animals. Numerous previous studies have proven it is beneficial to plants, however, it is considered nonessential for plant growth and development. Se plays an important role in the growth, development, and maintenance of the immune system of human and animals (Shenkin, 2006; Yadav et al., 2005; Speckmann and Grune, 2015). Se deficiency in the human body could cause about 40 kinds of diseases, such as Keshan and Kashin-Beck diseases (Tan et al., 2002; Zhang et al., 2014; Fernandes and Gandin, 2015; Chen et al., 2012; Kolesnikova et al., 2015). In 1982, it was reported that almost $72 \%$ of regions in China are facing the Se deficiency and about two-thirds of the population are experiencing 
deficiency of Se intake. Thus, the biofortification technology for increasing Se concentration in food crop has been paid more and more attentions by many researchers (Ma et al., 2008; Khanam and Platel, 2016).

Fertilization is short term and an effective method for improving micronutrient concentrations in food crop (Zhao and McGrath, 2009; Welch, 2008). Se fertilization is applied in soil and/or as a foliar application (Wang et al., 2017). Foliar fertilization is the most effective and safest way to increase the absorption of essential micronutrients in grain. Wheat is the most popular cereal crops worldwide and is a staple food for nearly half of the population in China where more than $85 \%$ of wheat is consumed as flour-derived products (Shewry, 2009; Li, 2006). Therefore, increasing Se nutrition in wheat grain is of the utmost importance when it comes to improving the nutritional status of people in China and other countries (Liu, 2007). In Hungary, colored-grain wheat cultivars are less known in contrast to East-Africa, New Zealand, Canada, and China, for example, where such forms occur in cultivated varieties (Varga et al., 2013). Wheat varieties with special colored-grain such as blue and purple grains had been proven to be rich in protein, amino acids, and trace elements or minerals (Zeven, 1991). It is well known that anthocyanins are functioning as antioxidants and, in addition, they also have anti-carcinogenic effects. Similarly, Se has anti-carcinogenic capabilities. Because of these health benefits, the combination of colored-grain wheat and Se is more beneficial to the development of food industry. Thus, colored-grain wheat is considered to be beneficial to the human body due to their high nutritional value and has become a special raw material for food industry (He et al., 2012). In addition, it was reported that colored-grain wheat was richer in Se than common wheat, suggesting a practical way to solve Se deficiency (Shi, 2006).

At present, there is little known about the enhancement of trace elements in coloredgrain wheat and Se-enriched colored-grain wheat has not been fully utilized. The purpose of this study is to evaluate the effect of biofortification of Se in colored-grain wheat in Se deficient region of Northern China. In the present study, field experiment was conducted to (i) investigate the uptake of Se concentration in grains from three different varieties of colored-grain winter wheat in the middle area of Shanxi province in China, (ii) evaluate the effect of foliar applications of $\mathrm{Se}$ on yield, protein concentration, the concentration of $\mathrm{Se}$ and other minerals, starch and amino acid concentration of the grain, and (iii) examine the relationship between $\mathrm{Se}$ and anthocyanin.

\section{Materials and methods}

\section{Field site description}

The field experiment was carried out from September 2016 to June 2017 in an experimental site at Shanxi Agricultural University, Taigu $\left(37^{\circ} 42^{\prime} \mathrm{N}, 112^{\circ} 58^{\prime} \mathrm{E}\right.$ ), Shanxi province, China (Fig. 1). The altitude of field experiment was 767-900 m, belong to the warm temperate zone continental climate, average annual precipitation was $450 \mathrm{~mm}$, average temperature was $10^{\circ} \mathrm{C}$ and average frost-free period is 160 $190 \mathrm{~d}$. The experimental field was plain and water land, planting one crop a year. There were four distinctive seasons. Soil samples were collected from the surface layer with a depth of $0-20 \mathrm{~cm}$ and the initial nutrient indices of the sampling soil were analyzed as follows: organic matter: $12.6 \mathrm{~g} \mathrm{~kg}^{-1}$; total nitrogen: $1.8 \mathrm{~g} \mathrm{~kg}^{-1}$; alkali-hydrolyzable nitrogen: $53.6 \mathrm{mg} \mathrm{kg}^{-1}$; available phosphorus: $9.6 \mathrm{mg} \mathrm{kg}^{-1}$; exchangeable potassium: 
$137.5 \mathrm{mg} \mathrm{kg}^{-1}$; total Se: $0.171 \mathrm{mg} \mathrm{kg}^{-1}$ and available zinc: $4.375 \mathrm{mg} \mathrm{kg}$. Above mentioned indices were measured using the methods of potassium dichromate volumetric, Kjeldahl determination, alkali-hydrolyzable proliferation, sodium bicarbonate extraction, ammonium acetate flame photometric, hydride generation atomic fluorescence spectrometry, and concentrations of DTPA-extractable micronutrients respectively.

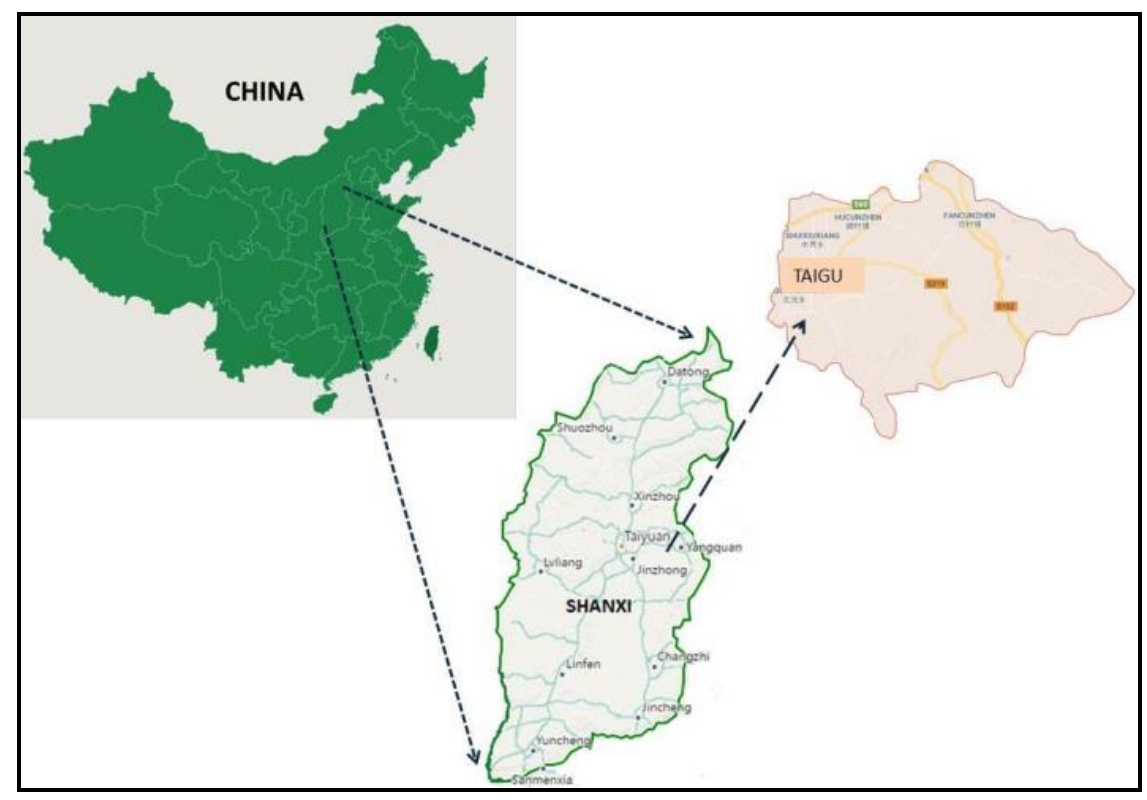

Figure 1. Map of experimental region in China

\section{Experimental design}

Two factors split plot design was used to optimize Se foliar fertilization content of colored-grain wheat by taking cultivars as a main factor and Se concentrations as a subplot factor. Three winter wheat cultivar Shannong 1 (purple), Shannong 031244 (blue), and Shannong 129 (white) were used in the experiment, among which Shannong 1 and Shannong 031244 were colored-grain wheat cultivar, while Shannong 129 was common wheat. Shannong 1 has a plant height of $60 \sim 70 \mathrm{~cm}$, compact plant type, neat tiller, high heading rate, long awn, purple seed coat and rapid grouting. Shannong 031244 has a plant height of $80 \sim 90 \mathrm{~cm}$, compact plant type, neat tiller, high heading rate, long awn, purple seed coat and rapid grouting. Shannong 129 has a plant height of $70 \sim 80 \mathrm{~cm}$, compact plant type, neat tiller, high heading rate, long awn, white seed coat and rapid grouting. Se was added in the form of $\mathrm{Na}_{2} \mathrm{SeO}_{3}$ at rates of 0 (control), $37.50 \mathrm{~g} \mathrm{ha}^{-1}, 56.25 \mathrm{~g} \mathrm{ha}^{-1}, 75.00 \mathrm{~g} \mathrm{ha}^{-1}, 93.75 \mathrm{~g} \mathrm{ha}^{-1}$, and $112.50 \mathrm{~g} \mathrm{ha}^{-1}$ respectively. The six concentrations of $\mathrm{Na}_{2} \mathrm{SeO}_{3}$ were diluted with distilled water. A handheld compression sprayer was used to spray foliar fertilizer uniformly and about $750 \mathrm{~L} \mathrm{ha}^{-1}$ solution was sprayed once. Wheat seeds were sown on September 30, 2016 at a sowing density of $600 \times 10^{4}$ plant ha $^{-1}$ and row spacing of $20 \mathrm{~cm}$. At the grain filling stage of winter wheat (May 20, 2017), each cultivar was sprayed with Se. No rainfall occurred after the spray. The plot sprayed with the same amount of distilled water was taken as the control. The harvest time was June 16, 2017. Each treatment was repeated three times. There were 54 plots in total. Area of each plot was $4 \mathrm{~m}^{2}(2 \mathrm{~m} \times 2 \mathrm{~m})$ and total 
area was $216 \mathrm{~m}^{2}$. Before sowing, $750 \mathrm{~kg} \mathrm{ha}^{-1}$ of NPK compound fertilizer $\left(\mathrm{N}: \mathrm{P}_{2} \mathrm{O}_{5}\right.$ : $\mathrm{K}_{2} \mathrm{O}=18 \%: 22 \%: 5 \%$ ) was applied as a based fertilizer. Other field management measures (such as irrigation and weed maintenance) were carried out as common practices (Fig. 2).

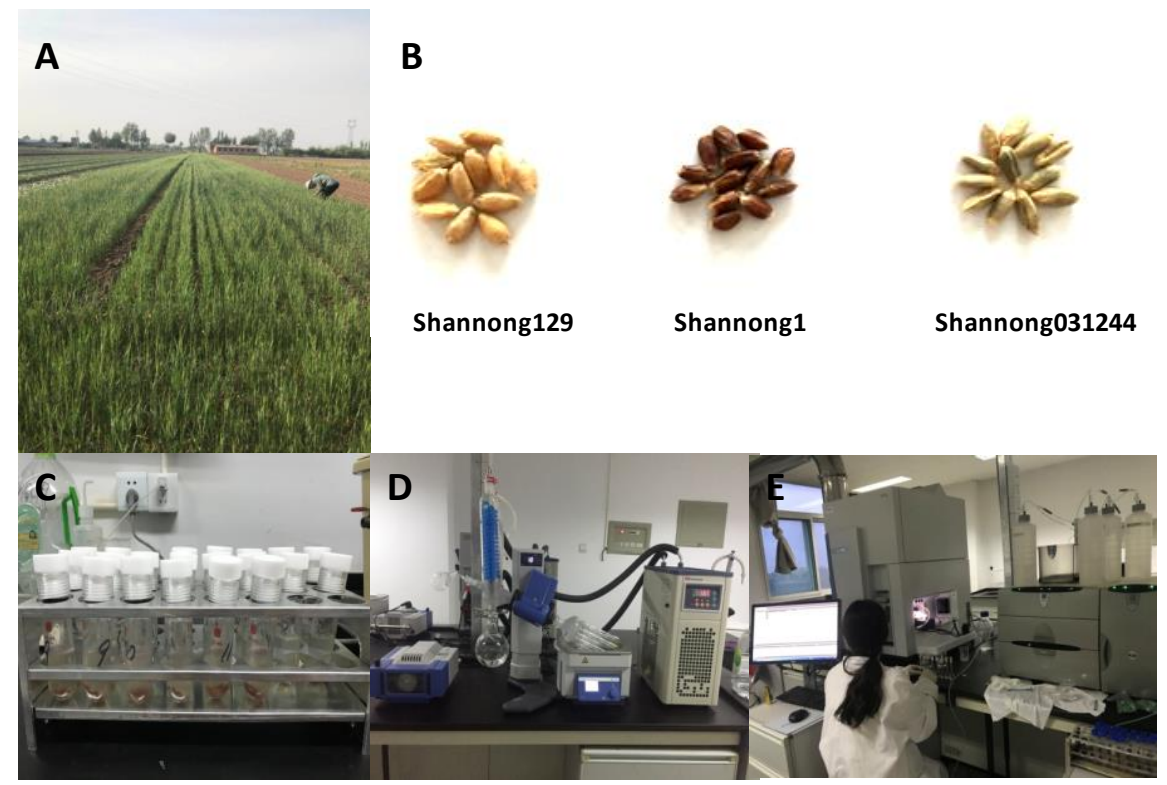

Figure 2. Sampling sites for indices analysis at Shanxi province, China

\section{Se and minerals analysis}

Wheat was harvested at full maturity stage to determine the yield as well as the contents of Se and minerals in grains. After determination of the yield, the obtained grain samples were washed carefully and rapidly with distilled water, and then dried at $65^{\circ} \mathrm{C}$ for $10 \mathrm{~h}$, grinded and sieved. The obtained flour samples were used to investigate the contents of total Se, minerals, protein, and the components. The flour samples were digested by using a $\mathrm{HNO}_{3}-\mathrm{H}_{2} \mathrm{O}_{2}$ mixture in an alimentary furnace reaction system (LWY84B, China), and then the concentration of Se and minerals were measured by using an inductively coupled plasma mass spectrometer (ICP-MS, Agilent 7700x; Agilent Technologies, USA) (Fig. 2).

\section{Protein and starch analysis}

The flour protein and its components were measured using Kjeldahl nitrogen method (He, 1985). Amylasein and amylopectin were determined by dual wavelength method. The sum of the amylasein and amylopectin is the total starch.

\section{Amino acids and anthocyanin analysis}

The hydrolyzed samples were analyzed according to the national food safety standard of the China (GB5009.124-2016). The grain were dried, crushe and sieved (< $0.15 \mathrm{~mm}$ ), which was weighed and put in the hydrolysis tube. First, $10 \mathrm{~mL} \mathrm{HCl}$ and phenol (3-4 drops) were added. Second, the hydrolysis tube was put into the refrigerant (3-5 $\mathrm{min}$ ) and attached to the suction pipe of the vacuum pump and fill nitrogen (fill 
nitrogen three times). After that the hydrolysis tube was sealed and put in thermostat $\left(110^{\circ} \mathrm{C}, 22 \mathrm{~h}\right)$. The hydrolysate was filtered into a $50 \mathrm{~mL}$ volumetric flask and constanted to the scale. The filtrate was put into the test tube. In a test tube enrichment apparatus decompression drying in $48^{\circ} \mathrm{C}$ heating environment. The dried residue was dissolved by water. Then the solution was vacuumed and dried again and until the top up. Finally, the buffer solution of $\mathrm{pH} 2.2$ sodium citrate was added to the test tube. The solution is to be measured passing through $0.22 \mathrm{~nm}$ membrane. Amino acid samples were separated by ion exchange chromatography and measured using the automatic amino acid analyzer (model Biochrom 30+, England). The anthocyanin analysis using pH differential method (Siriwoharn et al., 2004) (Fig. 2).

\section{Statistical analysis}

The experiment was laid out in a two factors split plot design with three parallel measurements. The data were subjected to a separate analysis of variance (ANOVA) for each cultivar, and the Tukey's multiple range test at $p<0.05$ was used to determine differences between treatment means. The Pearson correlation procedure and general line regression model was used to evaluate the relationship between grain $\mathrm{Se}$ and anthocyanin. SAS software (SAS 8.0, USA) was used for all analyses.

\section{Results}

\section{Grain yield and Se concentration}

To evaluate the effects of foliar application of Se fertilizer to the grain yield and Se concentration in grains, we conducted the ANOVA analyses on the grain yield, concentration of the grain total Se and grain Se cumulant. The grain yield and $\mathrm{Se}$ analysis carried out on the experimental field with the colored-grain wheat showed foliar application of Se fertilizer at different concentrations did not significantly affect the yield of colored-grains ( $p>0.05$, Table 1). The grain yield of Shannong 1 and Shannong 031244 were higher than Shannong 129.

Nevertheless, there were significant effects of the total Se and Se cumulant of three wheat varieties $(p<0.05)$. The total Se and Se cumulant of three wheat varieties were increased significantly with the increase the concentration of foliar Se fertilizer. By the foliar application of the same concentrations of Se at grain filling stage of different colored-grain wheat, results of the total Se and Se cumulant showed colored-grain wheat (Shannong 031244 and Shannong 1) > common-grain wheat (Shannong 129). Compared to the grain Se concentration in the untreated control, the concentration of added Se increased by up to 18-fold at the maximum Se application of Shannong 129. However, it increased up to 10-fold and 8-fold in the colored-grain wheat (Shannong 031244 and Shannong 1) respectively. It indicated that the wheat grain had strong ability to concentrate exogenous Se under the condition of foliar application. Although there was a increase between the total Se concentration and the amount of Se applied in the grain, the utilization rate of Se decreased with the increase of the concentration of foliar Se fertilizer. When the concentration of foliar Se fertilizer was $37.50 \mathrm{~g} \mathrm{ha}^{-1}$, utilization rate of Se reached the maximum, with the pattern of (Shannong 031244 and Shannong 1) > common-grain wheat (Shannong 129) displayed in three wheat varieties. According to the National Food Safety Standard in China, Se concentration in Seenriched wheat was prescribed in the range of $0.15-0.30 \mathrm{mg} \mathrm{kg}^{-1}$ (GB/T 22499-2008, 
China). When it was more than $0.30 \mathrm{mg} \mathrm{kg}^{-1}$, the high concentration could be unhealthy for humans. The Se concentration in the grain of common wheat was over the above range when foliar application of Se concentration greater than $75.00 \mathrm{~g} \mathrm{ha}^{-1}$. However, when foliar application of Se concentration was more than $37.50 \mathrm{~g} \mathrm{ha}^{-1}$, the Se concentration in the colored-grain wheat was excessive. The results indicated that colored-grain wheat was more sensitive to Se accumulation.

Table 1. Grain yield and Se concentration of colored-grain wheat affected by the different concentrations of Se fertilization

\begin{tabular}{|c|c|c|c|c|c|c|c|}
\hline \multicolumn{2}{|c|}{ Treatments } & \multicolumn{6}{|c|}{ Selenium $\left(g \cdot h a^{-1}\right)$} \\
\hline Indices & Cultivar & 0.00 & 37.50 & 56.25 & 75.00 & 93.75 & 112.50 \\
\hline \multirow{3}{*}{$\begin{array}{l}\text { Yield } \\
\left(\mathrm{t} \mathrm{ha}^{-1}\right)\end{array}$} & Shannong 129 & $5.48 \mathrm{aC}$ & $5.45 \mathrm{aC}$ & $5.42 \mathrm{aC}$ & $5.41 \mathrm{aC}$ & $5.41 \mathrm{aC}$ & $5.37 \mathrm{aC}$ \\
\hline & Shannong 031244 & $5.76 \mathrm{aB}$ & $5.77 \mathrm{aB}$ & $5.76 \mathrm{aB}$ & $5.70 \mathrm{aB}$ & $5.65 \mathrm{aB}$ & $5.62 \mathrm{aB}$ \\
\hline & Shannong 1 & $6.34 \mathrm{aA}$ & $6.42 \mathrm{aA}$ & $6.35 \mathrm{aA}$ & $6.39 \mathrm{aA}$ & $6.34 \mathrm{aA}$ & $6.33 \mathrm{aA}$ \\
\hline \multirow{3}{*}{$\begin{array}{l}\text { Grain total Se } \\
\text { concentration } \\
\quad\left(\mathrm{mg} \mathrm{kg}^{-1}\right)\end{array}$} & Shannong 129 & $0.024 \mathrm{eB}$ & $0.232 \mathrm{~dB}$ & $0.266 \mathrm{cdC}$ & $0.283 c \mathrm{C}$ & $0.350 \mathrm{bB}$ & $0.443 \mathrm{aB}$ \\
\hline & Shannong 031244 & $0.051 \mathrm{eA}$ & $0.272 \mathrm{dA}$ & $0.385 \mathrm{cA}$ & $0.498 \mathrm{bA}$ & $0.516 \mathrm{bA}$ & $0.541 \mathrm{aA}$ \\
\hline & Shannong 1 & $0.062 \mathrm{fA}$ & $0.285 \mathrm{eA}$ & $0.371 \mathrm{dA}$ & $0.475 \mathrm{cA}$ & $0.510 \mathrm{bA}$ & $0.539 \mathrm{aA}$ \\
\hline \multirow{3}{*}{$\begin{array}{l}\text { Grain Se cumulant } \\
\qquad\left(\mathrm{mg} \mathrm{ha}^{-1}\right)\end{array}$} & Shannong 129 & $130.45 \mathrm{eB}$ & $1267.92 \mathrm{dC}$ & $1441.15 \mathrm{cdB}$ & $1527.06 \mathrm{cB}$ & $1893.29 \mathrm{bC}$ & $2379.72 \mathrm{aC}$ \\
\hline & Shannong 031244 & $295.15 \mathrm{eA}$ & $1569.04 \mathrm{~dB}$ & $2216.23 \mathrm{cA}$ & $2835.68 \mathrm{bA}$ & $2913.87 \mathrm{bB}$ & $3040.98 \mathrm{aB}$ \\
\hline & Shannong 1 & 391.99fA & $1827.31 \mathrm{eA}$ & $2351.35 \mathrm{dA}$ & $3032.57 \mathrm{cA}$ & $3231.26 \mathrm{bA}$ & $3413.77 \mathrm{aA}$ \\
\hline \multirow{3}{*}{$\begin{array}{l}\text { Se utilization rate } \\
\qquad(\%)\end{array}$} & Shannong 129 & - & $3.03 \mathrm{aC}$ & $2.33 \mathrm{abB}$ & $1.86 \mathrm{bB}$ & $1.88 \mathrm{bB}$ & $2.00 \mathrm{bB}$ \\
\hline & Shannong 031244 & - & $3.40 \mathrm{aB}$ & $3.42 \mathrm{aA}$ & $3.39 \mathrm{aA}$ & $2.79 \mathrm{bA}$ & $2.44 \mathrm{cA}$ \\
\hline & Shannong 1 & - & $3.83 \mathrm{aA}$ & $3.37 \mathrm{aA}$ & $3.18 \mathrm{bA}$ & $3.03 \mathrm{bcA}$ & $2.69 \mathrm{cA}$ \\
\hline
\end{tabular}

Values were means of three replicates. Different line lowercase letters (a, b, c, d, e, f) indicated significant differences among Se treatments, at $\mathrm{p}<0.05$ in Tukey test. Different column uppercase letters (A, B, C) indicated significant differences among cus, at $\mathrm{p}<0.05$ in Tukey test

\section{Minerals concentration}

To further understand the effects of different concentrations of Se on colored-wheat grains, the concentration of mineral elements in colored-grain wheat are analyzed and shown in Figure 3. The concentration of mineral elements in colored-wheat grains was higher than that in common wheat, indicating that the nutritional value of colored-wheat was higher than that of common wheat. After leaves were sprayed with Se concentrations of $37.50 \mathrm{~g} \mathrm{ha}^{-1}$, the concentration of Iron (Fe) in Shannong 1 and Shannong 031244 were significantly increased by 1.2 -fold and 0.7 -fold, respectively ( $p$ $<0$. 05), the concentration of Zinc ( $\mathrm{Zn})$ in Shannong 1 and Shannong 031244 were significantly increased by 1.2 -fold and 0.7 -fold, respectively $(p<0.05)$. The concentration of $\mathrm{Fe}$ and $\mathrm{Zn}$ decreased but it was still hiher than the control value with the increase of Se concentration in foliar fertilizer. This indicates that the change of $\mathrm{Fe}$ and $\mathrm{Zn}$ in wheat grain presents a trend, which was low concentration promoted and high concentration inhibited by Se application. However, the supply of Se would inhibit the production of Copper $(\mathrm{Cu})$ and Manganese $(\mathrm{Mn})$. The decreased concentration range of $\mathrm{Cu}$ and $\mathrm{Mn}$ of all wheat were the same, indicating that the concentration variations of $\mathrm{Cu}$ and $\mathrm{Mn}$ of wheat grains were only affected by Se concentration other than wheat 
varieties. Overall, the results showed that the sensitivity of mineral concentration to Se in common wheat was lower than that of colored-grain wheat. The sensitivity of Se showed different in two colored-grain wheat, and purple wheat more sensitive than the blue one.
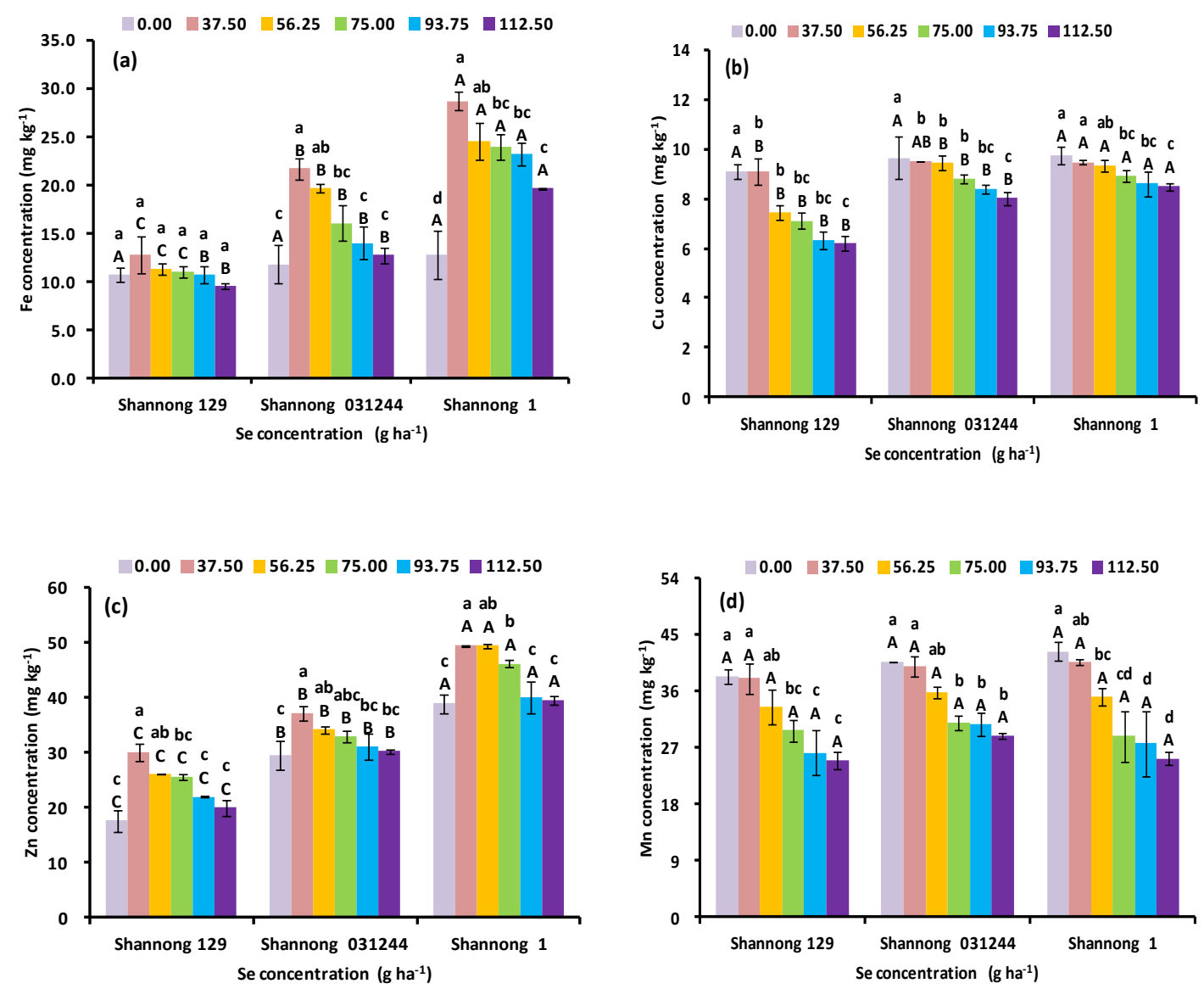

Figure 3. Minerals in grains of colored-grain wheat cultivar under foliar application of Se. $X$ axes show the concentrations of Se. Y axes show the concentrations of different minerals.

Values were means of three replicates. The subfigures $(a-d)$ show the concentrations of $\mathrm{Fe}, \mathrm{Cu}$, $\mathrm{Zn}$ and $\mathrm{Mn}$, respectively. Different line lowercase letters $(a, b, c, d)$ indicated significant differences among Se treatments, at $p<0.05$ in Tukey test. Different column uppercase letters $(A, B, C)$ indicated significant differences among cultivars, at $p<0.05$ in Tukey test.

\section{Concentration of total protein, protein components}

The concentrations of total protein and protein components showed significant changes within colored-grain wheat (Fig. 4, $p<0.05$ ). Overall, total protein concentration was significantly lower in Shannong 129 than in Shannong 031244 without Se $(p<0.05)$. The concentration of total protein increased with the increase the concentration of foliar Se fertilizer. The concentration of albumin and globulin were increased, however, which concentration Se increase amplitude gradually decreased with the increase the concentration of foliar Se fertilizer with the foliar application of $37.5 \mathrm{~g} \mathrm{ha}^{-1}$ which decreased at higher concentrations of Se, while gliadin and glutenin concentration $\mathrm{s}$ were increased in all wheat cultivar with increased concentrations of Se $(p<0.05)$. The highest gliadin and glutenin concentration was found at the highest 
concentration of Se. Glutenin concentration of colored-grain wheat (Shannong 1, Shannong 031244) was significantly higher than common wheat (Shannong 129); however, the concentration of albumin was highest in common wheat (Shannong 129). This indicates that the effect of foliar Se was significantly different for cultivar in terms of the protein components and total protein concentration.
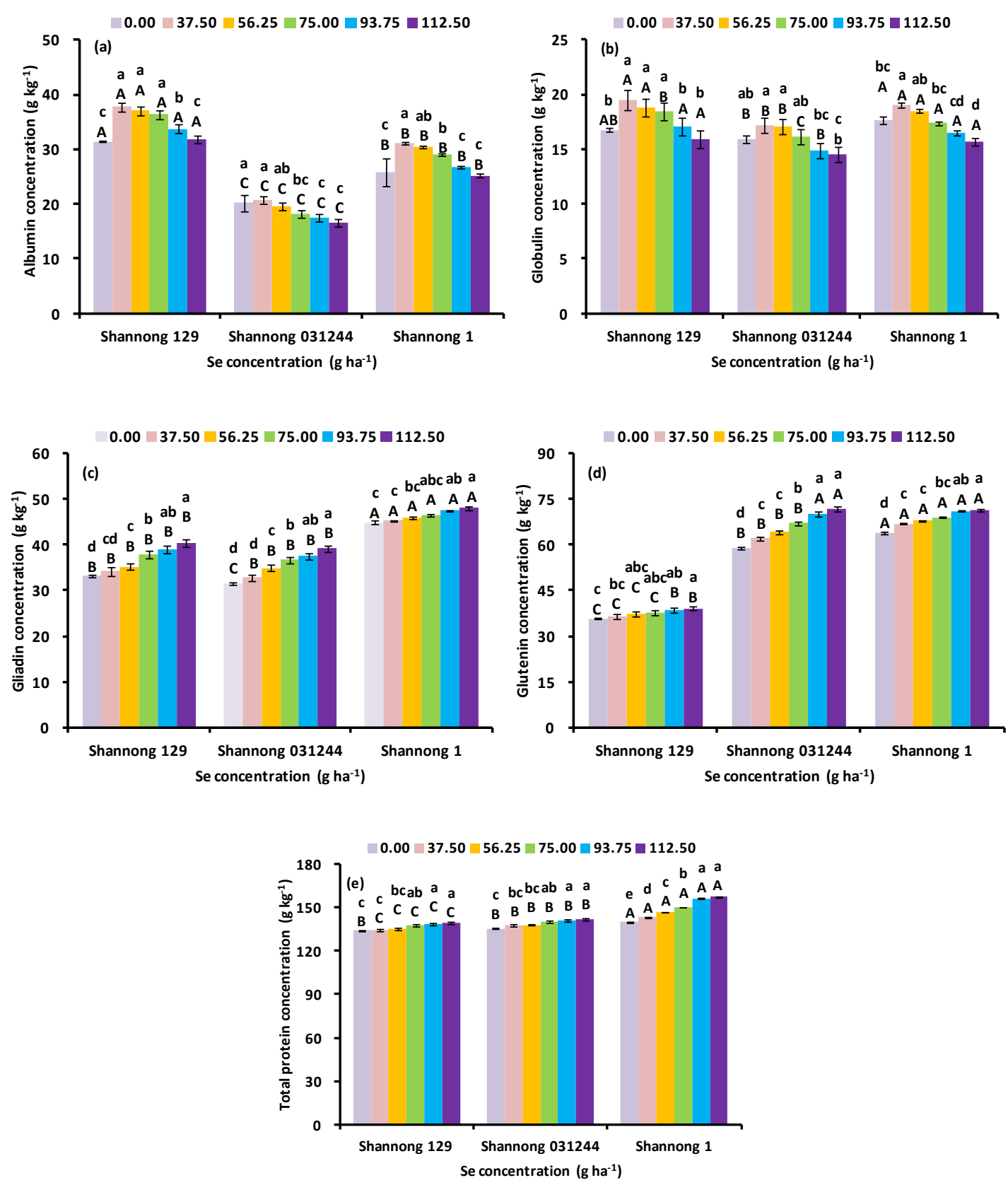

Figure 4. Concentrations of total protein and protein components in grains of colored-grain wheat cultivar under foliar application of Se.X axes show the concentrations of Se. Y axes show the concentrations of different concentrations of total starch and different starch components.

Values were means of three replicates. The subfigures (a-e) show the concentrations of albumin, globulin, gliadin, glutenin and total protein, respectively. Different line lowercase letters $(a, b$, $c, d)$ indicated significant differences among Se treatments, at $p<0.05$ in Tukey test. Different column uppercase letters $(A, B, C)$ indicated significant differences among cultivars, at $p<0.05$ in Tukey test. 


\section{Concentration of total starch and its components}

The concentration of total starch and its components showed significant changes within colored-grain wheat (Fig. 5, $p<0.05$ ). Overall, the concentration of amylase was significantly lower in Shannong 129 and Shannong 031244 than in Shannong 1 without Se $(p<0.05)$. The highest concentration of total starch and its components was found at the Se concentration of $37.5 \mathrm{~g} \mathrm{ha}^{-1}$ under foliar application. The concentration of total starch, amylase, and amylopectin first increased then decreased with the increase the concentration of foliar Se fertilizer. This indicates that the effect of foliar Se was significantly different for cultivar in terms of the starch components and total starch concentration.
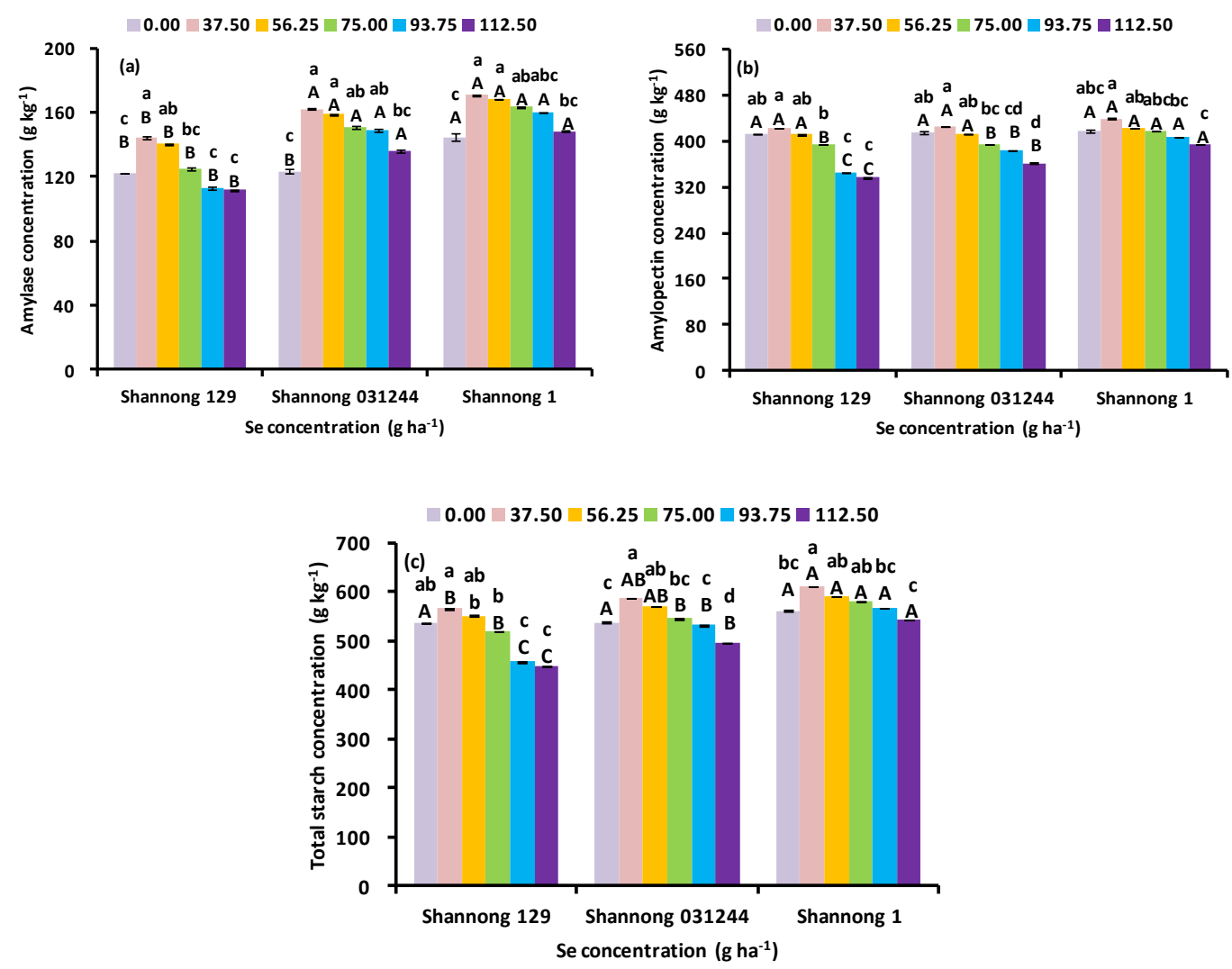

Figure 5. Concentrations of total starch and different starch components in grains of coloredgrain wheat cultivar under foliar application of Se. X axes show the concentrations of Se. Y axes show the concentrations of different concentrations of total starch and different starch components. Values were means of three replicates. The subfigures (a-c) show the concentrations of amylase, amylopectin and total starch, respectively. Different line lowercase letters $(a, b, c)$ indicated significant differences among Se treatments, at $p<0.05$ in Tukey test. Different column uppercase letters $(A, B, C)$ indicated significant differences among cultivars, at $p<0.05$ in Tukey test.

\section{Concentration of amino acids and anthocyanin}

The concentration of amino acids was higher in colored-grain wheat than in common grain wheat without Se treatment (Fig. 6). In the present study, a small dose of Se had a positive effect on the concentration of the total amino acids. 

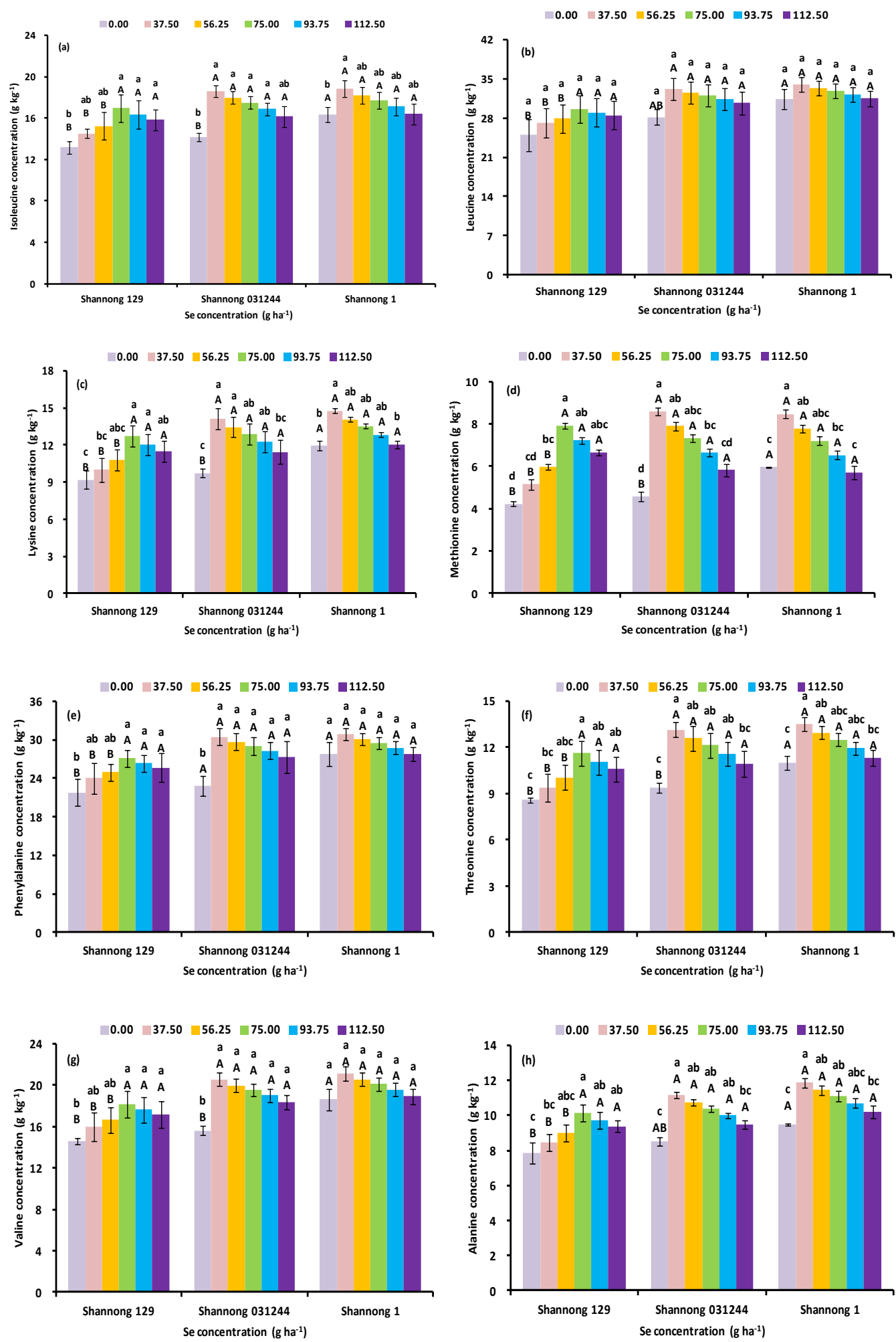

Figure 6. Concentrations of amino acids of colored-grain wheat affected by different concentrations of Se fertilization. $X$ axes show the concentrations of Se. $Y$ axes show the concentrations of different amino acids. Values were means of three replicates. The subfigures (a-p) show the concentrations of Ile, Leu, Lys, Met, Phe, Thr, Val, Ala, Arg, Asp, Glu, Pro, Gly,

His, Ser and Tyr, respectively. Different line lowercase letters $(a, b, c)$ indicated significant differences among Se treatments, at $p<0.05$ in Tukey test. Different column uppercase letters $(A, B, C)$ indicated significant differences among cultivars, at $p<0.05$ in Tukey test. 
However, higher levels of Se supplementation did not result in further increase of the concentration regarding the total amino acids. After applying a larger dose of Se, there was a small decrease in the total content of amino acids, but the overall concentration of amino acids was still larger than the control. There was a decreased trend after application Se concentration of $37.50 \mathrm{~g} \mathrm{ha}^{-1}$ in colored-grain wheat, however, a decreased trend was found after Se concentration of $75.00 \mathrm{~g} \mathrm{ha}^{-1}$ in common-grain wheat. The sixteen amino acids were detected (including seven essential amino acids and nine non-essential amino acids). All essential amino acids were significantly affected except leucine (Leu) $(p<0.05)$. The concentration of essential amino acids was significantly lower in Shannong 129 than in Shannong 1 and Shannong 031244 with Se. However, with the increase of Se concentration in foliar fertilizer, there were no significant effects of the essential amino acids of three wheat varieties $(p>0.05)$. The results for non-essential amino acids are also listed. The application of Se markedly influenced the concentration of non-essential amino acids except arginine (Arg) and tyrosine (Tyr) $(p<0.05)$. Meanwhile, with the increase of Se concentration in foliar fertilizer, there were aslo no significant effects of the non-essential amino acids of three wheat varieties $(p>0.05)$.

To examine the relationship between anthocyanins and Se, the concentration of anthocyanins was measured in colored-grain wheat (Fig. 7). We found the synergistic effect between anthocyanins and Se in colored-grain wheat, which indicated there was likely to be a great Se-enrichment potential in colored-grain wheat.

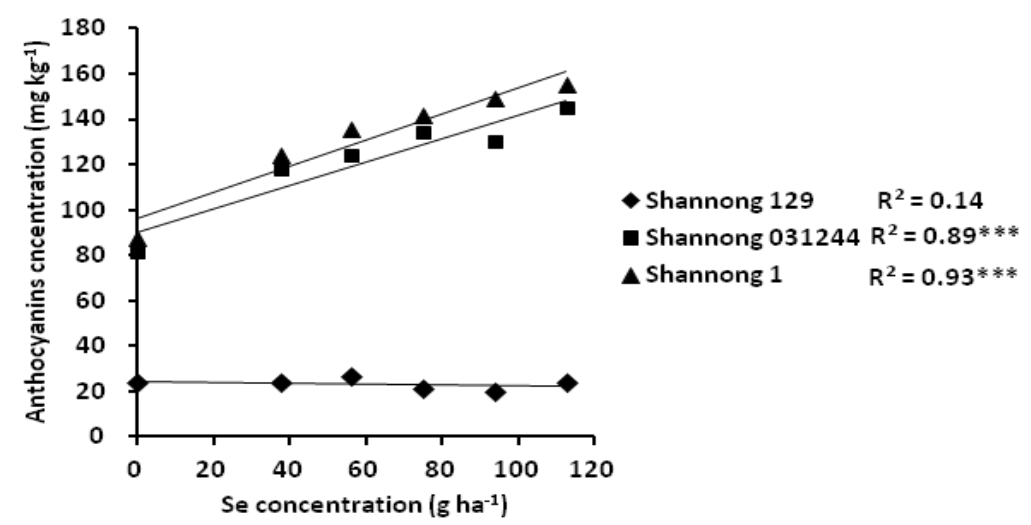

Figure 7. The correlation between anthocyanin and foliar application of Se in grains of colored-grain wheat. X axes show the concentrations of Se. Y axes show the concentrations of different minerals

\section{Discussion}

The customer's acceptance of innovative, new products is dependent on their feedback to the sensory and functional properties of flour, including color, flavor, nutritional value, and overall acceptability. In particular, for flour, it is necessary to maintain the typical sensory and nutritional characteristics for commercial success in the development of functional foods. The evidence that Se enrichment of colored-grain wheat improves the nutritional aspect of the flour without altering its sensory properties is critical for consumers to accept Se-enriched flour (Ficco et al., 2014). However, nutritional analyses of bio-fortified colored-grain wheat flour have not been studied extensively. Our study focused on the evaluation of the effect of Se on the nutritional 
contents of colored-grain wheat and provided a valuable practice on the development of new functional selenium-fortified colored-grain wheat.

The soil Se-supplement, dress seeds, soaking seeds, foliar application of Se and exogenous Se supplementation can increase the amount of Se in agricultural products (Ducsay et al., 2009). Among above foliar application of Se has the advantages of fast, efficient, low cost and low environmental risk. Our findings suggested the effectiveness of foliar Se fertilization as a suitable strategy to improve nutritional quality of coloredgrain wheat, which is consistent with the previous studies which have shown the greater effectiveness of foliar Se treatment than other Se supply methods in wheat (Zhang et al., 2010; Galinha et al., 2015). Moreover, we found that all of the Se treatments were highly effective at increasing the Se concentration in the colored-grain wheat, for three wheat cultivars, and that the Se concentrations in the grain increased with increasing concentrations of Se application according to a positive correlation. This evidence is in agreement with several previous studies in which high correlation values were observed (Broadley et al., 2010; Rodrigo, Santamaría, López-Bellido and Poblaciones, 2013). The Se-enriched wheat required Se concentration to be $0.15-0.30 \mathrm{mg} \mathrm{kg}^{-1}$ (GB/T 224992008, China). Therefore, appropriate external Se will be necessary to make up the deficiency to develop the Se-enriched wheat flour. In our result, when the foliar application of Se at the optimal dose $\left(37.5 \mathrm{~g} \mathrm{ha}^{-1}\right)$, the concentration of Se in coloredgrain wheat had reached the above standard. When the wheat flour above this standard will not be good for people to eat. The absence of Se poisoning observed in our study is an important consideration for farmers, because this foliar Se application could not cause any reductions in yield through a wide range of Se concentrations.

There was no significant difference in the yield of colored-grain wheat by foliar application of selenium fertilization, which was consistent with the previous studies, in which pre-harvest foliar application of mineral elements did not affect grain yield of crops (Chen et al., 2002; Rodrigo et al., 2013). There was much research about the effect of foliar application Se on common wheat, but little research has been done on colored-grain wheat. In the control group of our study, the Se concentration in the common wheat grain was a little lower than in the colored-grain wheat, which confirmed high nutritional value in the colored-grain wheat. The concentration of Se and the accumulation of Se increased with the increase of Se concentration; however, the increase varies depending on wheat varieties. The Se concentration in colored-grain wheat was significantly higher than common grain wheat which might be caused by the absorption, transformation, and transport capacity of the exogenous sodium Se solution of colored-grain wheat. The utilization efficiency of Se in wheat is similar to other elements, that is, under relatively stable technical conditions, the Se concentration of wheat increased with the increase of Se injection, but the utilization of Se goes down. This explains the high concentration of Se inhibited plant growth due to Se toxicity interfering with the plant metabolism. Clearly, our results showed the beneficial role of Se at low concentrations could promote colored-grain wheat growth, which is consistent with previous studies (Boldrin et al., 2016; Guerrero et al., 2014). For the first time, we compared the Se accumulation between common wheat and colored-grain wheat, and reported the significant increase of mineral concentrations in the colored-grain varieties comparing to the common variety, which indicated a great potential to increase the nutritional content of colored-grain wheat flour for the commercial uses by the strategy of Se foliar spray. 
It is generally considered that high dosages of Se may be toxic to plants by competing with some essential elements, such as $\mathrm{Mn}, \mathrm{Zn}, \mathrm{Cu}$ and $\mathrm{Fe}$ (Kabata-Pendias and Pendias, 2011; Fargasova et al., 2006), however, in some cases, the stimulating effects of Se on uptakes of $\mathrm{Cu}, \mathrm{Fe}$ and $\mathrm{Zn}$ in plants were also observed (Feng et al., 2009). Intriguingly, foliar application of $\mathrm{Se}$ had a significant effect on mineral concentrations in wheat grains. The colored-grain wheat varieties had significantly higher mineral concentration than the common wheat. Our results showed foliar application of Se promoted the accumulation of $\mathrm{Fe}$ and $\mathrm{Zn}$ and inhibited $\mathrm{Cu}$ and $\mathrm{Mn}$ accumulation, similar to the previous suggestion by Feng et al. (2009).

As Se is incorporated into proteins as selenoaminoacids, the different aptitudes of these colored-grain varieties to accumulate Se might be linked to dissimilarities in their protein content (Barclay and MacPherson, 1992). If the protein content in wheat grain is high, Se is mainly associated with plant proteins. Nossier et al. (2011) found selenium was related to protein function. Se was further reported to be involved in protein metabolism as a component in an RNA chain in plants, with the main physiological function of transporting amino acids to synthesize proteins (Garousi, 2017; Schiavon et al., 2017). In our research, Se foliar fertilizer showed a significant impact on protein components in grains of colored-grain wheat varieties too. The content of albumin and globulin were significantly reduced but the content of gliadin and glutenin were significantly increased with the increase the concentration of foliar Se fertilizer. The significant effect of the high Se concentration on the protein components of coloredgrain wheat was observed, with being more prominent in the deeper colored varieties. Furthermore, there was no effect of Se fertilization on gluten quality, similar to previous suggestions by Broadley et al. (2010). In addition to the protein components, the Se fertilization had no effect on either gluten or fat parameters, which indicated the foliar spray of Se will not affect other main organic nutrient than proteins in colored-grain wheat. Furthermore, the starch is the main source of wheat extract. In theory, amylose was converted into fermentable sugar and amylopectin was converted into fermentable sugar and low molecular dextrin under the action of enzyme. The possible reason for the decline of starch is that the high dose of Se supply made the grain filling speed decrease, thus preventing the transformation of starch component.

The significant influence of amino acid concentration in plant tissues can be caused by nutrition and fertilization, such as Se (Munshi, 1990). For exemple, methionine (Met) was the limiting essential amino acid, and application of Se in our study affected the Met content of colored-grain wheat. Moreover, the application of Se markedly influenced the content of aspartic acid (Asp) and Asparagine (Asn) which is resulted from amidation of Asp. Both Asp and Asn are important in the transport and storage of nitrogen in plant tissues (Lea et al., 2007). In addition, we found the synergistic effect between anthocyanins and Se in colored-grain wheat, which indicated there was likely to be a great Se-enrichment potential in colored-grain wheat.

In the future studies, the following aspects are expected to be focused: (i) The physiological regulation mechanism of Se in the process of migration, distribution, and accumulation in colored-grain wheat plants and the antagonistic mechanism of Se and heavy metals in colored-grain wheat plants. (ii) Further uses of advanced biotechnology on selecting and breeding new varieties of Se-enriched colored-grain wheat. 


\section{Conclusion}

It is the first time to report the Se-enrich colored-grain wheat with the nutritional analyses and evaluation upon different Se concentrations applied in foliar spray. The optimal fertilization of Se could enhance nutritional quality of colored-grain cultivar including the concentrations of protein, minerals and amino acid without affecting the grain yield, gluten, and fat content, however, the starch concentration was decreased. Additionally, wheat grain was reported to be enriched with Se through exogenous Se under the foliar application of Se. Thus, the foliar application of Se at the optimal dose (37.5 $\mathrm{g} \mathrm{ha}^{-1}$ ) is suggested to be used for Se bio-fortification of colored-grain wheat cultivar. Moreover, the purple grain wheat is more Se-enriched than blue one. Further studies are expected to understand the mechanisms of micro-nutrient uptake and transport to acquire more efficient accumulation of nutrients in colored-grain wheat. Our study provides a valuable practice in nutrition analyses of the colored-grain wheat and the development of nutrient-enriched wheat flour.

Acknowledgements. The authors wish to thank the mediums and sitters who volunteered their time for this study. This study was financially supported by the Shanxi Scholarship Council of China from the Ministry of Finance, PR of China (2015-Key4), the the Key project of Shanxi Key R\&D Program of China (201703D211001-02) and the Special Plan of Scientific Research for Shanxi Agriculture Valley of China (SXNGJSKYZX 201702) and the China Agriculture Research System (CARS-03-01-24).

\section{REFERENCES}

[1] Barclay, M. N. I., MacPherson, A. (1992): Selenium content of wheat for bread making in Scotland and the relationship between glutathione peroxidase (EC 1.11. 1.9) levels in whole blood and bread consumption. - British Journal of Nutrition 68(1): 261-270.

[2] Boldrin, P. F., de Figueiredo, M. A., Yang, Y., Luo, H., Giri, S., Hart, J. J., ... Li, L. (2016): Selenium promotes sulfur accumulation and plant growth in wheat (Triticum aestivum). - Physiologia Plantarum 158(1): 80-91.

[3] Broadley, M. R., Alcock, J., Alford, J., Cartwright, P., Foot, I., Fairweather-Tait, S. J., ... Meacham, M. C. (2010): Selenium biofortification of high-yielding winter wheat (Triticum aestivum L.) by liquid or granular Se fertilisation. - Plant and Soil 332(1-2): 518.

[4] Chen, J. S. (2012): An original discovery: selenium deficiency and Keshan disease (an endemic heart disease). - Asia Pacific Journal of Clinical Nutrition 21(3): 320-326.

[5] Chen, L., Yang, F., Xu, J., Hu, Y., Hu, Q., Zhang, Y., Pan, G. (2002): Determination of selenium concentration of rice in China and effect of fertilization of selenite and selenate on selenium content of rice. - Journal of Agricultural and Food Chemistry 50(18): 51285130.

[6] Ducsay, L., Ložek, O., Varga, L. (2009): The influence of selenium soil application on its content in spring wheat. - Plant Soil Environ 55(2): 80-84.

[7] Fargasova, A.; Pastierova, J.; Svetkova, K. J. P. S. (2006): Effect of Se-metal pair combinations $(\mathrm{Cd}, \mathrm{Zn}, \mathrm{Cu}, \mathrm{Pb})$ on photosynthetic pigments production and metal accumulation in Sinapis alba L. seedlings. - Plant Soil \& Environment 52(1): 8-15.

[8] Feng, R.; Wei, C.; Tu, S.; Wu, F. J. P. (2009): Effects of Se on the uptake of essential elements in Pteris vittata L. - Plant \& Soil 325(1-2): 123-132.

[9] Fernandes, A. P., Gandin, V. (2015): Selenium compounds as therapeutic agents in cancer. - Biochimica et Biophysica Acta (BBA)-General Subjects 1850(8): 1642-1660. 
[10] Ficco, D. B., Mastrangelo, A. M., Trono, D., Borrelli, G. M., De Vita, P., Fares, C., ... Papa, R. (2014): The colours of durum wheat: a review. - Crop and Pasture Science 65(1): 1-15.

[11] Galinha, C., Sánchez-Martínez, M., Pacheco, A. M., do Carmo Freitas, M., Coutinho, J., Maçãs, B., ... Wolterbeek, H. T. (2015): Characterization of selenium-enriched wheat by agronomic biofortification. - Journal of food science and technology 52(7): 4236-4245.

[12] Garousi, F. (2017): The essentiality of selenium for humans, animals, and plants, and the role of selenium in plant metabolism and physiology. - Acta Universitatis Sapientiae, Alimentaria 10(1): 75-90.

[13] Guerrero, B., Llugany, M., Palacios, O., Valiente, M. (2014): Dual effects of different selenium species on wheat. - Plant Physiology and Biochemistry 83: 300-307.

[14] He, Y. Z., Lei, X. G., Zhang, C. D., Gu, Z. J., Wang, Y., Ning, J. F. (2012): Research of Nutritional Quality and Utilization of Iron Zinc-Rich Colored Wheat. - Journal of Plant Genetic Resources 13(4): 672-677 (in Chinese with English abstract).

[15] He, Z. F. (1985): Quality of Cereal and Oil Grains and Its Analysis Technology. Agricultural Press $<$ Beijing, pp. 290-301 (in Chinese with English abstract).

[16] Kabata-Pendias, A. (2011): Trace Elements in Soils and Plants. - CRC Press, Boca Raton, FL.

[17] Kennedy, G., Nantel, G., Shetty, P. (2003): The scourge of "hidden hunger": global dimensions of micronutrient deficiencies. - Food Nutrition and Agriculture (32): 8-16.

[18] Khanam, A., Platel, K. (2016): Bioaccessibility of selenium, selenomethionine and selenocysteine from foods and influence of heat processing on the same. - Food Chemistry 194: 1293-1299.

[19] Kolesnikova, L. I., Karpova, E. A., Vlasov, B. Y., Sukhov, B. G., Mov, T. (2015): Lipid peroxidation-antioxidant defense system during toxic liver damage and its correction with a composite substance containing selenium and arabinogalactan. - Bulletin of Experimental Biology and Medicine 159(2): 225.

[20] Lea, P. J., Sodek, L., Parry, M. A., Shewry, P. R., Halford, N. G. (2007): Asparagine in plants. - Annals of Applied Biology 150(1): 1-26.

[21] Li, Q. L. (2006): The produce and consumption of wheat and wheat flour in China. Flour Milling 5: 9-14 (in Chinese with English abstract).

[22] Liu, Z. H., Wang, H. Y., Wang, X. E., Zhang, G. P., Chen, P. D., Liu, D. J. (2007): Phytase activity, phytate, iron, and zinc contents in wheat pearling fractions and their variation across production locations. - Journal of Cereal Science 45(3): 319-326.

[23] Ma, G., Jin, Y., Li, Y., Zhai, F., Kok, F. J., Jacobsen, E., Yang, X. (2008): Iron and zinc deficiencies in China: what is a feasible and cost-effective strategy? - Public Health Nutrition 11(6): 632-638.

[24] Maberly, G. F., Trowbridge, F. L., Yip, R., Sullivan, K. M., West, C. E. (1994): Programs against micronutrient malnutrition: ending hidden hunger. - Annual Review of Public Health 15(1): 277-301.

[25] Munshi, C. B., Combs Jr, G. F., Mondy, N. I. (1990): Effect of selenium on the nitrogenous constituents of the potato. - Journal of Agricultural and Food Chemistry 38(11): 2000-2002.

[26] Nossier, M. I. E. H. (2011): Effect of Selenium on Uptake and Assimilation of Some Plant Nutrients. - Ain Shams Univ. Faculty of Agriculture, Cairo, Egypt.

[27] Rodrigo, S., Santamaría, O., López-Bellido, F. J., Poblaciones, M. J. (2013): Agronomic selenium biofortification of two-rowed barley under Mediterranean conditions. - Plant, Soil and Environment 59(3): 115-120.

[28] Schiavon, M., Lima, L. W., Jiang, Y., Hawkesford, M. J. (2017): Effects of Selenium on Plant Metabolism and Implications for Crops and Consumers. - In: Pilon-Smits, E. A. H. et al. (eds.) Selenium in Plants (pp. 257-275). Springer, Cham.

[29] Shenkin, A. (2006): The key role of micronutrients. - Clinical Nutrition 25(1): 1-13.

[30] Shewry, P. R. (2009): Wheat. - Journal of Experimental Botany 60(6): 1537-1553. 
[31] Shi R L, Zhou C Q, Zhang F S, et al. (2006): Research progress on grain iron and zinc nutrition and human health. - Guangdong Microelement Science 13(7): 1-8 (in Chinese with English abstract).

[32] Siriwoharn, T., Wrolstad, R. E., Finn, C. E., Pereira, C. B. (2004): Influence of cultivar, maturity, and sampling on blackberry (Rubus L. Hybrids) anthocyanins, polyphenolics, and antioxidant properties. - Journal of Agricultural and Food Chemistry 52(26): 80218030.

[33] Speckmann, B., Grune, T. (2015): Epigenetic effects of selenium and their implications for health. - Epigenetics 10(3): 179-190.

[34] Tan, J. A., Zhu, W., Wang, W., Li, R., Hou, S., Wang, D., Yang, L. (2002): Selenium in soil and endemic diseases in China. - Science of the Total Environment 284(1-3): 227235.

[35] Toppe J, Chomo, V. (2015): Second International Conference on Nutrition (ICN2): Contribution of Fish to Human Nutrition. - FAO Aquaculture Newsletter (53): 4.

[36] Varga, M., Bánhidy, J., Cseuz, L., Matuz, J. (2013): The anthocyanin content of blue and purple coloured wheat cultivars and their hybrid generations. - Cereal Research Communications 41(2): 284-292.

[37] Wang, S., Li, M., Liu, K., Tian, X., Li, S., Chen, Y., Jia, Z. (2017): Effects of Zn, macronutrients, and their interactions through foliar applications on winter wheat grain nutritional quality. - PloS One 12(7): e0181276.

[38] Welch, R. M. (2008): Linkages between Trace Elements in Food Crops and Human Health. - In: Alloway, B. J. (ed.) Micronutrient Deficiencies in Global Crop Production. Springer, Dordrecht, pp. 287-309.

[39] Yadav, S. K., Singh, I., Singh, D., Han, S. D. (2005): Selenium status in soils of northern districts of India. - Journal of Environmental Management 75(2): 129-132.

[40] Zeven, A. C. (1991): Wheats with purple and blue grains: a review. - Euphytica 56(3): 243-258.

[41] Zhang, Y., Shi, R., Rezaul, K. M., Zhang, F., Zou, C. (2010): Iron and zinc concentrations in grain and flour of winter wheat as affected by foliar application. Journal of Agricultural and Food Chemistry 58(23): 12268-12274.

[42] Zhang, Z., Zhang, J., Xiao, J. (2014): Selenoproteins and selenium status in bone physiology and pathology. - Biochimica et Biophysica Acta (BBA)-General Subjects 1840(11): 3246-3256.

[43] Zhao, F. J., McGrath, S. P. (2009): Biofortification and phytoremediation. - Current Opinion in Plant Biology 12(3): 373-380.

[44] Zhao, Q G, Yin, X. B. (2016): Functional Agriculture. - The Science Publishing Company (in Chinese with English abstract). 